\title{
Prognostic Role of Interleukin-23 in Prostate Adenocarcinoma: Comparison with Gallium-68 Prostate-Specific Membrane Antigen-11 Positron Emission Tomography/Computed Tomography Findings
}

\author{
İnterlökin-23'ün Prostat Adenokarsinomundaki Prognostik Rolü: Galyum-68 Prostat \\ Spesfik Membran Antijeni-11 Pozitron Emisyon Tomografi/Bilgisayarlı Bulguları ile \\ Karşılaştırma
}

\author{
(D) Cihan Gündoğan1, (D) Nurhan Ergül1, (D) Huriye Serin², (D) Ediz Beyhan1, (D) Burçak Yılmaz¹, (D) Tevfik Fikret Çermik1 \\ 1 University of Health Sciences Turkey, İstanbul Training and Research Hospital, Clinic of Nuclear Medicine, İstanbul, Turkey \\ 2University of Health Sciences Turkey, İstanbul Training and Research Hospital, Clinic of Biochemistry, İstanbul, Turkey
}

\begin{abstract}
Introduction: Androgen deprivation therapy is the first line of treatment for advanced prostate cancer (PC). However, PC progressed in most patients when it becomes resistant to castration. This study aimed to investigate the possible role of interleukin-23 (IL-23), a cytokine expressed in various cancers, in the development of resistance to castration and prognosis in PC.
\end{abstract}

Methods: Twenty-three patients with PC were consecutively enrolled in the study to undergo gallium-68 (Ga-68) prostatespecific membrane antigen (PSMA) positron emission tomography/computed tomography (PET/CT). Among those patients, 13 were newly diagnosed as treatment-naive (ND), while 10 were evaluated for disease progression under hormonotheraphy. Before PET/CT, $5 \mathrm{~mL}$ of venous blood samples was obtained from the study participants. Serum levels of IL-23 were determined by enzyme-linked immunosorbent assay using an IL-23 receptor kit. The relationship of ND and castration-resistant (CR) groups with serum IL-23 level and the correlation of the rate of lymph node involvement, skeletal and distant metastasis Gleason scores, prostate-specific antigen (PSA) levels, and maximum standardized uptake value (SUV ${ }_{\text {max }}$ ) of the prostate gland with IL-23 levels were analyzed.

Results: Ga-68 PSMA PET/CT revealed that 13 (56.5\%) patients had skeletal metastases, 10 (43.5\%) had non-pelvic nodal metastasis, and $3(13 \%)$ had distant-organ metastasis. The difference between the serum IL-23 levels of the ND group and the CR group was not significant $(p=0.664)$. The IL-23 levels were not significantly different between patients with and
öZ

Amaç: Androjen yoksunluğu tedavisi, ileri evre prostat kanseri (PK) için ilk tedavi seçeneğidir. Ancak çoğu hastada tedavi süresince hastalık kastrasyona dirençli hale geldiğinde progresyon görülür. Çeșitli kanser türlerinde eksprese edilen bir sitokin olan interlökin-23'ün (IL-23) PK'de kastrasyona direnç gelişimi ve prognozdaki olası rolünü araştırmayı amaçladık.

Yöntemler: Galyum-68 (Ga-68) prostat spesfik membran antijeni (PSMA) pozitron emisyon tomografi/bilgisayarlı tomografi (PET/BT) görüntülemesi için çalıșmaya $23 \mathrm{PK}$ hastası alındı. Bunlardan 13'ü yeni tanılı-tedavi görmemiş (YT) hastalarken, 10'u hormonoterapi altında hastalık ilerlemesi açısından değerlendiriliyordu. PET/BT görüntülemeden önce çalıșma katılımcılarından beș mililitre venöz kan örneği alındı. IL-23'ün serum seviyeleri, bir IL-23 reseptör kiti kullanılarak ELISA testi ile belirlendi. YT olgular ve kastrasyon dirençli olguların ilișkisi serum IL-23 seviyesi ile analiz edildi ve ayrıca lenf nodu, iskelet ve uzak metastaz tespit oranı, Gleason skorları, prostat spesifik antijen (PSA) seviyeleri ve IL-23 seviyeleri ile prostat bezinin SUV ${ }_{\max }$ ile arasındaki ilișki seviyeleri araștırıldı.

Bulgular: Ga-68 PSMA PET/BT'de 13 (\%56,5) hastada iskelet metastazı, 10 'unda $(\% 43,5)$ pelvik olmayan nodal metastaz ve 3'ünde (\%13) metastatik uzak organ yayılımı saptandı. YT hastalar ile kastrasyon dirençli hastaların serum IL-23 düzeyleri arasındaki fark istatistiksel olarak anlamlı değildi $(p=0,664)$. IL-23 düzeyleri metastatik hastalığı olan ve olmayan hastalar arasında anlamlı farklılık göstermedi. Ayrıca yaş, IL23 seviyeleri ve total PSA seviyelerinin yanı sıra primer tümör
This study was presented as an oral presentation in the 33 European Association of Nuclear Medicine Congress (Virtual) on October 22-30, 2020.

Address for Correspondence/Yazıșma Adresi: Nurhan Ergül MD, University of Health Sciences Turkey, İstanbul Training and Research Hospital, Clinic of Nuclear Medicine, İstanbul, Turkey

Phone: +90 2124596454 E-mail: nurhanergul@yahoo.com ORCID ID: orcid.org/0000-0002-8214-9743

Cite this article as/Atıf: Gündoğan C, Ergül N, Serin H, Beyhan E, Yılmaz B, Çermik TF. Prognostic Role of Interleukin-23 in Prostate Adenocarcinoma: Comparison with Gallium-68 Prostate-Specific Membrane Antigen-11 Positron Emission Tomography/Computed Tomography Findings. İstanbul Med J 2021; 22(4): 320-5.
Received/Geliș Tarihi: 15.03.2021 Accepted/Kabul Tarihi: 13.10.2021

(C) Copyright 2021 by the University of Health Sciences Turkey, Istanbul Training and Research Hospital/istanbul Medical Journal published by Galenos Publishing House.

(C) Telif Hakkı 2021 Sağıı Bilimleri Üniversitesi Istanbul Ĕgitim ve Araştırma Hastanesi/Istanbul Tıp Dergisi, Galenos Yayınevi tarafından basılmıștır. 
without metastatic disease. Further, no significant association was found among age, IL-23 levels, and total PSA levels as well as primary tumor SUV max $_{\text {an }}$ and serum IL-23 levels.

Conclusion: Although a significant correlation was found between serum IL-23 levels and the development of castration resistance, the metastatic stage and SUV ${ }_{\max }$ were not proven decisively. Thus, it can be assumed that IL-23 has no major role in the development of castration resistance and prognosis in PC.

Keywords: Interleukin-23, prostate adenocarcinoma, Ga-68 PSMA-11 PET/CT
SUV $_{\max }$ değerleri ve serum IL-23 seviyeleri arasında istatistiksel olarak anlamlı bir ilișki yoktu.

Sonuç: Serum IL-23 seviyeleri ile kastrasyona direnç gelișimi, metastatik hastalık ve SUV ${ }_{\max }$ değerlerinin arasında anlamlı bir ilişki olmadığı için, IL-23'ün PK'nin prognozunda yeri olmadığı söylenebilir.

Anahtar Kelimeler: İnterlökin-23, prostat adenokarsinomu, Ga-68 PSMA-11 PET/BT

\section{Introduction}

Prostate cancer (PC) is the second leading cause of cancer-related death in men. Androgen deprivation therapy (ADT) is the first line of treatment for advanced PC. The androgen blockade at the castration level, where the serum testosterone level is $<50 \mathrm{ng} / \mathrm{mL}$, regresses the disease by causing both apoptosis and a pause in the division of cancer cells. Treatment response is evaluated based on a decrease in tumor size and reduced serum prostate-specific antigen (PSA) levels. An increase in PSA levels during the disease course indicates resistance to androgen blockade. Although various mechanisms have been proposed in the pathophysiology of castration resistance, many factors are still unclarified $(1,2)$. Oncogene activation, inactivation of tumor-suppressor genes, intratumoral androgen production, and aberrant androgen receptor activation are known mechanisms in the development of this resistance (3).

Calcinotto et al. (4) proposed that interleukin-23 (IL-23), which is released from myeloid-derived suppressor cells, a group of immune cells consisting of monocytes and neutrophils, may cause castration resistance by interacting with the IL-23 receptor in PC cells. They reported that the serum and tissue levels of IL-23 were significantly higher in patients who developed castration resistance than in those sensitive to castration. Moreover, they showed that when an antibody blocking IL23, i.e., enzalutamid, an androgen receptor blocker, was administered to castration-resistant (CR) mice, the castration resistance was reversed, and the tumor size shrunk $(4,5)$.

Prostate-specific membrane antigen (PSMA) is a transmembrane receptor protein widely expressed in PC cells. Molecules labeled with radioisotopes targeting this receptor are used in both $\mathrm{PC}$ diagnosis and treatment. Various studies have shown that gallium-68 (Ga-68) PSMA positron emission tomography/computed tomography (PET/CT) aids in determining the response to treatment in patients receiving ADT and in the detection of tumor focus in patients with biochemical recurrence $(6,7)$. In this prospective study, we investigated the role of serum IL-23 levels, a cytokine expressed in many cancers, and its correlation with Ga-68 PSMA PET/CT findings in the development of castration resistance and the prediction of PC prognosis.

\section{Methods}

\section{Patients}

This study included 23 patients with PC (median age: 72 years; range: 55-89 years), who were referred to our clinic for Ga-68 PSMA PET/CT for either staging or restaging purposes. The study was approved by the University of Health Sciences Turkey, İstanbul Training and Research Hospital Institutional Review Board (approval number: 1668, date: 01/02/2019). Written consent was obtained from all included patients for the use of their clinical findings for research purposes.

Among those 23 patients, 13 were newly diagnosed as treatmentnaive (ND), while 10 were evaluated for disease progression under hormonotherapy (HT) and classified as having CRPC.

Patients whose PC progressed while under chemotherapy or those who had received chemotherapy before HT were excluded from the study. On the day of PET/CT, $5 \mathrm{~mL}$ of venous blood was obtained from all patients before the administration of the radiopharmaceutical agent. The plasma was separated and stored at $80{ }^{\circ} \mathrm{C}$ for later analysis.

\section{Measurement of IL-23 Concentration}

The IL-23 concentration in the plasma was measured using a human IL-35 enzyme-linked immunosorbent assay kit (Catalog No. E2164Hu, Bioassay Technology Laboratory, China) according to the manufacturer's protocol. Each sample was assayed three times.

\section{Imaging}

A whole-body PET scan (from vertex to upper thighs) was acquired using a Biograph mCT 20 PET/CT scanner (Siemens Molecular Imaging; Hoffman Estates, IL, USA) 60 min after intravenous injection of Ga-68 PSMA-11 (median: $175 \mathrm{MBq}$; range: 77-350 MBq). The maximum standardized uptake values $\left(\right.$ SUV $\left._{\max }\right)$ of the primary tumors were acquired from the area of the prostate gland with the highest uptake. Areas in the whole body with uptake above the background activity were defined as metastatic. Metastatic disease was defined according to the current guidelines, i.e., lymph nodes in the true pelvis as pelvic lymph node metastasis (PLNM; N1), extrapelvic lymph node metastasis (EPLNM; M1a), bone metastasis (BM; M1b), and metastasis in other sites with or without bone metastasis (MOS; M1C).

The IL-23 levels were compared between the CRPC group and ND group. The IL-23 levels were also compared between patients according to prognostic factors including Gleason score $(7$ and $>7)$ and presence of metastatic disease. The correlation between age, IL-23 levels, and total PSA levels were investigated. The correlation of IL-23 and prostate SUV ${ }_{\max }$ levels was also analyzed in the ND group. 


\section{Statistical Analysis}

Data are presented as mean, median, standard deviation, and percentages. All analyses were performed using IBM SPSS Statistics version 20.0 (IBM Corp. Armonk, NY, USA). Normality was evaluated using Kolmogorov-Smirnov test. Comparisons between groups of quantitative variables were performed using the Mann-Whitney U test for two independent subgroups. Spearman correlation coefficient was evaluated for correlations. All tests were two-tailed, and $p<0.05$ was considered significant.

\section{Results}

Ga-68 PSMA PET/CT revealed that 17 of 23 (73.9\%) patients (7 CRPC, 10 ND) had PLNM, 10 of 23 (43.4\%) patients (8 CRPC, 2 ND) had EPLNM, 13 (56.5\%) patients (9 CRPC, 4 ND) had BM, and 3 (13.0\%) patients (2 CRPC, $1 \mathrm{ND}$ ) had MOS (Figure 1, 2).

In the CRPC group, 4 of 10 patients had increased PSA levels while under HT. Although all four had M1b disease, they did not undergo PSMA PET/ CT previously and the progression in PET could not be evaluated. Four patients with elevated PSA levels also demonstrated progression based on Ga-68 PSMA-11 PET/CT findings. Two patients had stable or decreased PSA levels, despite progression noted in Ga-68 PSMA-11 PET/CT: one patient had M1b and one had M1c disease (Figure 3).

No significant difference was observed in serum IL-23 levels between the ND group and CRPC group $(p=0.664)$. Similarly, no significant difference was found between IL-23 levels of patients with Gleason score 7 or $\geq 7$ ( $p=0.295)$, with or without PLNM ( $p=0.529)$, with or without EPLNM $(p=0.951)$, with or without BM $(p=0.901)$, and with or without $\operatorname{MOS}(p=0.784$; Table 1$)$.
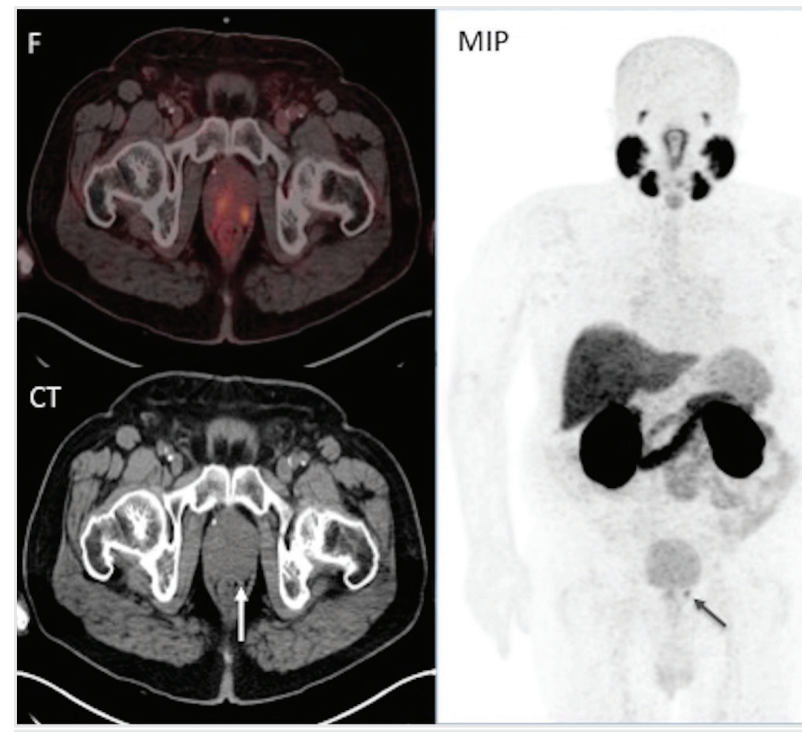

Figure 1. A 69-year-old man with newly diagnosed PC, Gleason score of $4+3$, tPSA of $6.25 \mathrm{ng} / \mathrm{mL}$, and IL-23 of $303.6 \mathrm{pg} / \mathrm{mL}$. On Ga-68 PSMA PET/ $\mathrm{CT}$, only the primary lesion in the prostate gland (SUV $\left.{ }_{\max }: 7.2\right)$ was observed with no lymph node or distant metastasis

PC: Prostate cancer, tPSA: Total prostate-specific antigen, F: Fusion, CT: Computed tomography, MIP: Maximum intensity projection image, Ga-68: Gallium-68, PSMA: Prostate-specific membrane antigen, PET/CT: Positron emission tomography/ computed tomography, SUV ${ }_{\max }$ : Maximum standardized uptake value, IL: Interleukin
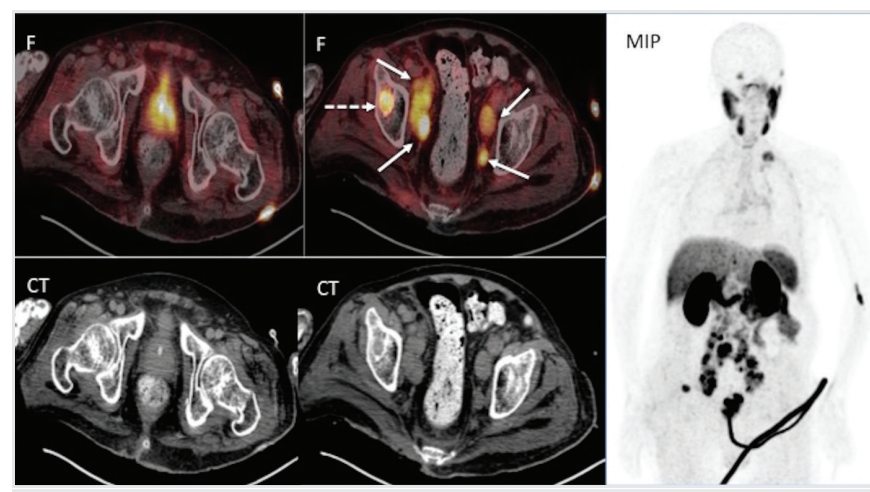

Figure 2. A 63-year-old man with newly diagnosed PC, Gleason score of $4+3$, tPSA of $185 \mathrm{ng} / \mathrm{mL}$, and IL-23 of $339.6 \mathrm{pg} / \mathrm{mL}$. On Ga-68 PSMA PET/CT, the primary lesion in prostate gland involving both seminal vesicles (SUV 49.1), multiple metastatic lymph nodes in the abdominopelvic (arrows) and left supraclavicular regions and pelvic bone metastasis (dashed arrow) were observed

PC: Prostate cancer, tPSA: Total prostate-specific antigen, F: Fusion, CT: Computed tomography, MIP: Maximum intensity projection image, Ga-68: Gallium-68, PSMA: Prostate-specific membrane antigen, PET/CT: Positron emission tomography/

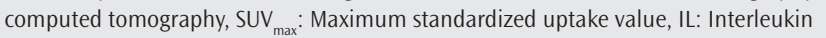

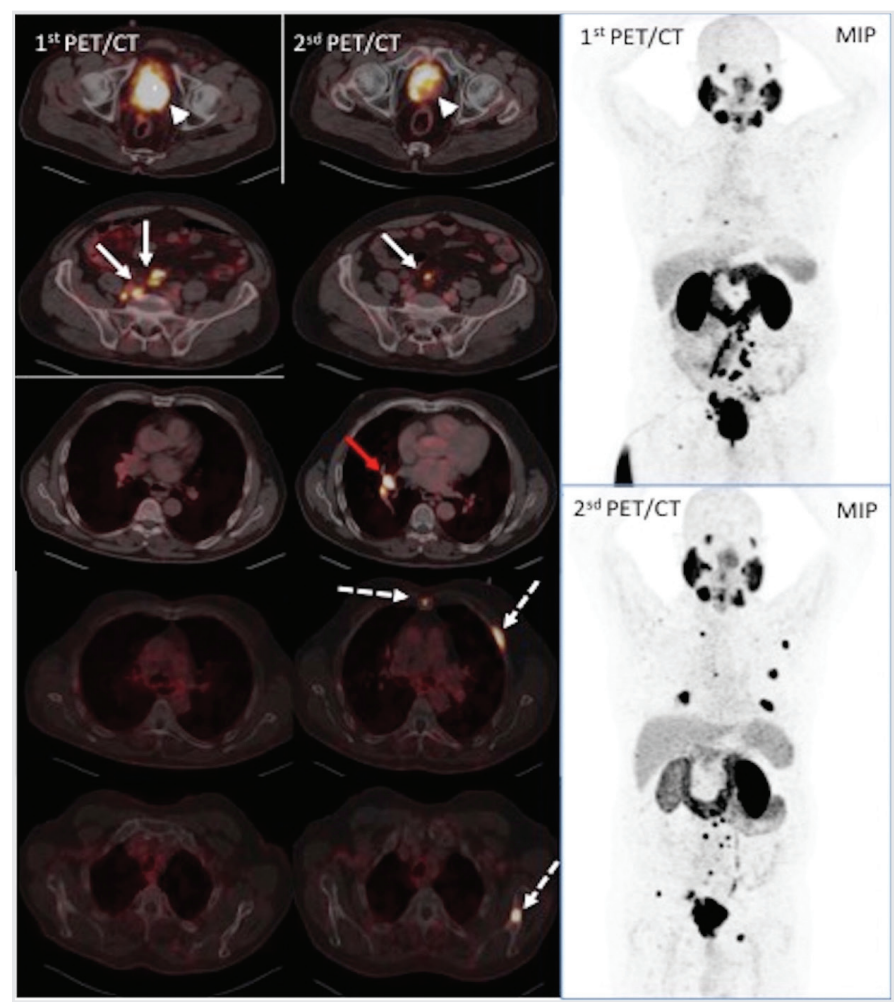

Figure 3. A 72-year-old man with PC and Gleason score of 3+5. He had been receiving hormonotherapy for 3 years. The tPSA level decreased from $54.3 \mathrm{ng} / \mathrm{mL}$ to $3.1 \mathrm{ng} / \mathrm{mL}$ between Ga-68 PSMA PET/CT scans at 6 months interval. However, in follow-up scan, while the primary lesion in the prostate gland and pelvic lymph nodes partially regressed, there were newly developed mediastinal metastatic lymph nodes and multiple bone metastases (fusion and maximum intensity projection images). The IL-23 level at the second PET/CT scan was $110.2 \mathrm{pg} / \mathrm{mL}$ (below the mean value of newly diagnosed cases with $316.02 \pm 85.94 \mathrm{pg} / \mathrm{mL}$ )

PC: Prostate cancer, tPSA: Total prostate-specific antigen, F: Fusion, CT: Computed tomography, MIP: Maximum intensity projection image, Ga-68: Gallium-68, PSMA: Prostate-specific membrane antigen, PET/CT: Positron emission tomography/ computed tomography, SUV max $_{\text {: }}$ Maximum standardized uptake value, IL: Interleukin 
No significant correlation was observed among patients' age, total PSA levels, and IL-23 levels (Table 2). The ND group showed no significant

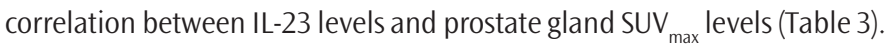

\section{Discussion}

Many studies have investigated the prognostic effects of cytokines in PC. A very recent study found that IL-8 expression in the tumor microenvironment was associated with aggressive PC and androgen receptor loss in metastatic disease (8). Plasma IL-35 levels in patients with PC were reported to be significantly higher than those in patients with benign prostatic hyperplasia and healthy controls. Another study reported that increased IL-35 expression was associated with progression of disease stage and shorter survival (9). In another study, transforming growth factor- $\beta 1$ was higher in prostate hyperplasia tissue samples than in PC samples, while IL-6 expression was significantly higher in PC samples than in hyperplasia samples (10). In PC, IL-15 was shown to stimulate the expansion of natural killer cells and was considered for intra-tumor therapy (11).

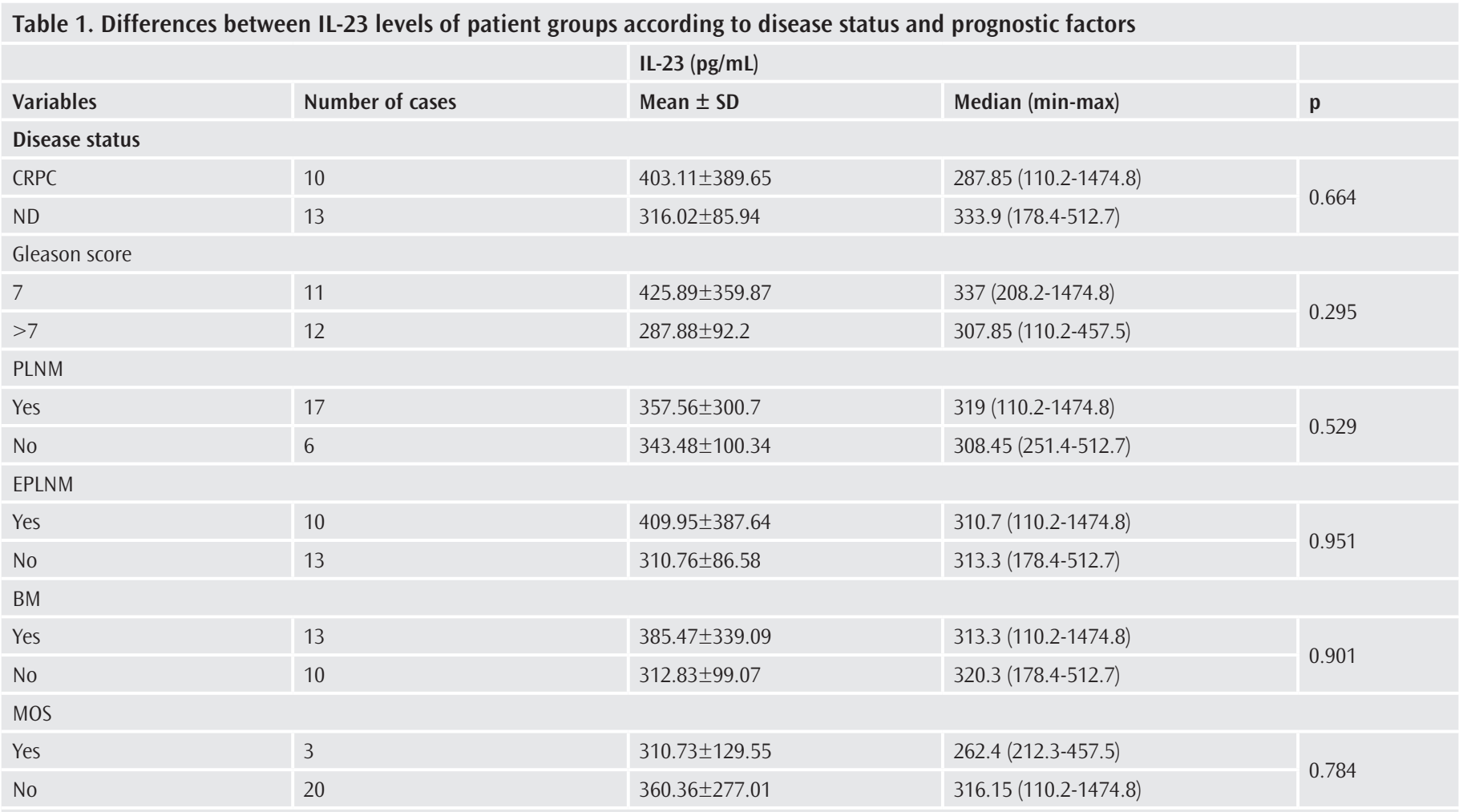

CRCP: Castration-resistant prostate cancer, ND: Newly diagnosed, PLNM: Pelvic lymph node metastasis, EPLNM: Extrapelvic lymph node metastasis, BM: Bone metastasis, MOS: Metastasis of other sites, SD: Standard deviation, IL: Interleukin, min: Minimum, max: Maximum

Table 2. Relationship among age, IL-23 levels, and tPSA levels

\begin{tabular}{|l|l|l|}
\hline All patients $(\mathbf{n}=\mathbf{2 3})$ & Mean \pm SD & Median $(\mathbf{m i n}-$ max $)$ \\
\hline Age & $710.4 \pm 8.42$ & $72(55-89)$ \\
\hline IL-23 $(\mathrm{pg} / \mathrm{mL})$ & $353.89 \pm 260.93$ & $313.3(110.2-1474.8)$ \\
\hline Total PSA & $60.23 \pm 121.6$ & $13(2.77-562)$ \\
\hline & Correlation (Spearman) & \\
\hline Age/IL-23 & $\mathrm{rs}=-0.195, \mathrm{p}=0.373$ & \\
\hline Age/tPSA & $\mathrm{rs}=0.245, \mathrm{p}=0.259$ & \\
\hline tPSA/IL-23 & $\mathrm{rs}=-0.053, \mathrm{p}=0.809$ & \\
\hline IL: Interleukin, SD: Standard deviation, min: Minimum, max: & Maximum, tPSA: Total prostate-specific antigen \\
\hline
\end{tabular}

Table 3. Relationship between IL-23 levels and prostate SUVmax levels of newly diagnosed cases

\begin{tabular}{|l|l|l|}
\hline Newly diagnosed cases $(\mathbf{n}=\mathbf{1 3})$ & Mean \pm SD & Median (min-max) \\
\hline IL-23 $(\mathrm{pg} / \mathrm{mL})$ & $316.02 \pm 85.94$ & $333.9(178.4-512.7)$ \\
\hline Prostate SUV & $22.91 \pm 20.73$ & $13.4(6.7-74.3)$ \\
\hline Prostate $_{\text {max }} /$ IL-23 & rs=-0.258, $\mathrm{p}=0.394$ & \\
\hline
\end{tabular}

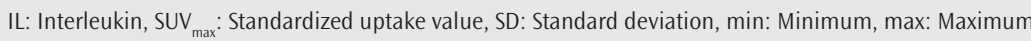


The effects of IL-12, IL-23, IL-27, and IL-35, which are members of the IL12 cytokine families, on immune response in many diseases have been assessed in numerous studies. While the antitumor effects of IL-12 on various cancers are known, IL-23 was found to promote tumor growth by upregulating proangiogenic factors and increasing the mobility of tumor cells. Preclinical experiments showed that approaches that change the IL-12 and IL-23 levels in the tumor microenvironment can provide synergistic effects with other anticancer treatments. Moreover, IL-23, which is expressed in many cancers, could be an important therapeutic target (12). IL-23 is also proposed as a possible factor in the pathogenesis and disease progression of colorectal cancer $(13,14)$. Another study showed that patients with breast cancer having higher IL-23 levels had poorer overall survival, suggesting a negative prognostic correlation (15).

In locally advanced and metastatic PC, ADT is the first and main disease management. For determining the therapy options in the ND group, Ga-68 PSMA PET/CT was showed to be effective in staging and revealing regional and distant metastases (16). However, most patients develop resistance to ADT after a short time, and the disease progresses. An increase in PSA level is the most commonly used marker of disease progression. However, in some patients with stable or slightly elevated PSA levels, Ga-68 PSMA PET/CT can accurately reveal disease progression as in two of our patients with CRPC. The available chemotherapy regimens containing docetaxel and cabazitaxel have moderate survival benefits (3). Unraveling the mechanisms that cause the development of resistance to androgen blockade will lead to significant improvements in guiding treatment.

Calcinotto et al. (4) revealed the possible association of IL-23 with castration resistance. They proposed that, under androgen-deprived conditions, IL-23 could activate the androgen receptor pathway in prostate tumor cells, promoting cell survival and proliferation. Moreover, they found that elevated IL-23 concentration in the blood and tumor samples from patients with CRPC and that antibody-mediated inactivation of IL-23 restored sensitivity to ADT in mice (5). These results are important for creating possible future treatments that block IL-23 and reverse the castration resistance. However, our results did not show any significant relationship between blood levels of IL-23 and castration resistance or poor prognostic factors in patients with PC.

\section{Study Limitations}

This study has several limitations including its limited sample size and that lack of comparison with a healthy control group. The lack of IL23 measurement in prostate tissue samples is another limitation since correlation analysis with blood IL-23 levels was not performed.

\section{Conclusion}

Our findings failed to demonstrate a possible benefit of blocking the IL-23 pathway in patients with PC to reverse the castration resistance or avoid disease metastasis. In advanced metastatic disease, Ga-68 PSMA $\mathrm{PET} / \mathrm{CT}$ can reveal the progression and resistance to ADT more accurately than PSA measurements, and radionuclide therapies targeting the PSMA receptor should be considered earlier than other possible therapy options.
Ethics Committee Approval: The study was approved by the University of Health Sciences Turkey, İstanbul Training and Research Hospital Institutional Review Board (approval number: 1668, date: 01/02/2019).

Informed Consent: Written consent was obtained from all included patients for the use of their clinical findings for research purposes.

Peer-review: Externally peer-reviewed.

Authorship Contributions: Surgical and Medical Practices - C.G., H.S., E.B., B.Y., T.F.Ç.; Concept - T.F.C..; Design - C.G., N.E., T.F.Ç.; Data Collection or Processing - C.G., H.S., E.B., B.Y., T.F.C..; Analysis or Interpretation C.G., N.E., H.S., E.B., B.Y., T.F.C.; Literature Search - N.E.; Writing - N.E.

Conflict of Interest: No conflict of interest was declared by the authors.

Financial Disclosure: The authors declared that this study received no financial support.

\section{References}

1. Watson PA, Arora VK, Sawyers CL. Emerging mechanisms of resistance to androgen receptor inhibitors in prostate cancer. Nat Rev Cancer 2015; 15: 701-11.

2. Karantanos T, Corn PG, Thompson TC. Prostate cancer progression after androgen deprivation therapy: mechanisms of castrate resistance and novel therapeutic approaches. Oncogene 2013; 32: 5501-11.

3. Kahn B, Collazo J, Kyprianou N. Androgen Receptor as a Driver of Therapeutic Resistance in Advanced Prostate Cancer. Int J Biol Sci 2014; 10: 588-95.

4. Calcinotto A, Spataro C, Zagato E, Di Mitri D, Gil V, Crespo M, et al. IL23 secreted by myeloid cells drives castration resistant prostate cancer. Nature 2018; 559: 363-9.

5. Yan J, Cua DJ, Teng MWL. IL-23 promotes the development of castrationresistant prostate cancer. Immunol Cell Biol 2018; 96 :883-5.

6. Kuten J, Sarid D, Yossepowitch O, Mabjeesh NJ, Even-Sapir E. [68Ga]GaPSMA-11 PET/CT for monitoring response to treatment in metastatic prostate cancer: is there any added value over standard follow-up? EJNMMI Res 2019; 9: 84 .

7. Fendler WP, Calais J, Eiber M, Flavell RR, Mishoe A, Feng FY, et al. Assessment of 68Ga-PSMA-11 PET accuracy in localizing recurrent prostate cancer: a prospective single-arm clinical trial. JAMA Oncol 2019; 5: 856-63.

8. Maynard JP, Ertunc 0, Kulac I, Baena-Del Valle JA, De Marzo AM, et al. IL8 Expression Is Associated with Prostate Cancer Aggressiveness and Androgen Receptor Loss in Primary and Metastatic Prostate Cancer. Mol Cancer Res 2020; 18: 153-65.

9. Zhu J, Yang X, Wang Y, Zhang H, Guo Z. Interleukin-35 is associated with the tumorigenesis and progression of prostate cancer. Oncol Lett 2019; 17: 5094 102.

10. Afdal A, Darwin E, Yanwirasti Y, Hamid R. The expression of transforming growth factor beta-1 and interleukin-6 on human prostate: prostate hyperplasia and prostate cancer. Open Access Maced J Med Sci 2019; 7: 190510

11. Sakellariou C, Elhage O, Papaevangelou E, Giustarini G, Esteves AM, Smolarek $D$, et al. Prostate cancer cells enhance interleukin-15- mediated expansion of NK cells. BJU Int 2020; 125: 89-102.

12. Yan J, Smyth MJ, Teng MWL. Interleukin (IL)-12 and IL-23 and Their Conflicting Roles in Cancer. Cold Spring Harb Perspect Biol 2018; 10: a028530.

13. Elessawi DF, Alkady MM, Ibrahim IM. Diagnostic and prognostic value of serum IL-23 in colorectal cancer. Arab J Gastroenterol 2019; 20: 65-8. 
14. Hu WH, Chen HH, Yen SL, Huang HY, Hsiao CC, Chuang JH. Increased expression of interleukin-23 associated with progression of colorectal cancer. J Surg Oncol 2017; 115: 208-12.

15. Gangemi S, Minciullo P, Adamo B, Franchina T, Ricciardi GR, Ferraro M, et al. Clinical significance of circulating interleukin-23 as a prognostic factor in breast cancer patients. J Cell Biochem 2012; 113: 2122-5.
16. Ergül N, Yilmaz Güneș B, Yücetaş U, Toktaş MG, Çermik TF. 68Ga-PSMA-11 PET/ CT in Newly Diagnosed Prostate Adenocarcinoma. Clin Nucl Med 2018; 43: e422-7. 